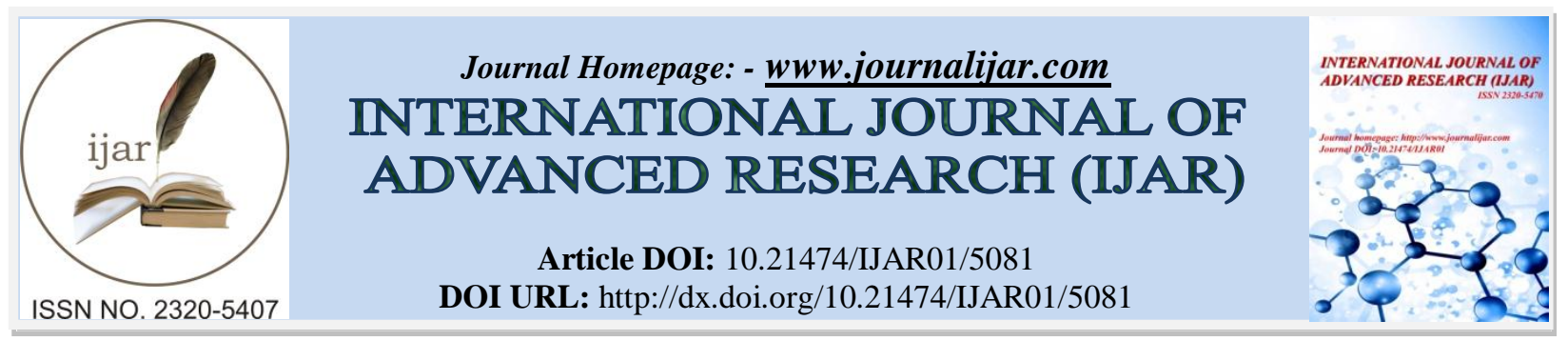

RESEARCH ARTICLE

\title{
THEVETIA PERUVIANA: A MULTIPURPOSE MEDICINAL PLANT- A REVIEW.
}

"Tabrez Ahmad ${ }^{1}$, Abdulhamid Tahir Hamid ${ }^{2}$, Anuradha Sharma ${ }^{1}$ and Uma Bhardwaj ${ }^{3}$.

1. Department of Biotechnology, School of Life and Applied Sciences, Baba Farid Institute of Technology, Dehradun, Uttarakhand, India.

2. School of Biotechnology, Maharaj Vinayak Global University, Jaipur, Rajasthan, India.

3. Dean Research, Swami Rama Himalayan University, Dehradun, Uttarakhand, India.

\section{Manuscript Info}

Manuscript History

Received: 05 June 2017

Final Accepted: 07 July 2017

Published: August 2017

Key words:-

Thevetia peruviana, Apocynaceae,

Cardiac glycosides,

Ethanopharmacology

\section{Abstract}

Plant based therapeutics play an important role in the public health care system of any nation. The plant Thevetia peruviana belongs to the family Apocynaceae. The plant have a significant place in traditional system of medicine of Central and South America and tropical Asia. A number of different classes of secondary metabolites are present in Thevetia peruviana including alkaloids, flavonoids, steroids, cardiac glycosides, terpenoids, tannins, saponins etc. Several researchers had identified various pharmacological activities in different parts of the plant viz. seeds, flowers, bark, fruits, leaves. This review covers detailed ethanopharmacology, toxicology and bioactivities of Thevetia peruviana.

Copy Right, IJAR, 2017,. All rights reserved.

\section{Introduction:-}

Our planet is home for enormous medicinal plants. Mankind use of medicinal plants is not new rather dates back to thousands of years. In fact, ancient man was very dependent on green plants for his day-to-day needs of medicaments. When a plant is designated as medicinal, it is implied that the said plant is useful as a drug or therapeutic agent or an active ingredient of a medicinal preparation. Recently the demand for plant based therapeutics has increased steeply because of many loopholes in modern system of medicine such as various side effects and high cost. Moreover, increasing knowledge of metabolic process and the effect of plants on human physiology has enlarged the range of application of medicinal plants. The therapeutic properties of medicinal plants are attributed owing to the presence of active principles such as alkaloids, flavonoids, glycosides, terpenoids, tannins, coumarins, saponins etc.

Thevetia peruviana (pers) K Schum is a medicinal plant with wide array of pharmacological properties, but yet not received considerable scientific attention. The plant belongs to the family Apocynaceae and is commonly known as yellow oleander. The plant is native to Central and South America, especially Mexico, Brazil and West Indies but now frequently cultivated throughout the tropical including India and Srilanka as an ornamental plant.

\section{Description of the Plant:-}

Taxonomical Classification:

Kingdom : Plantae

Subkingdom : Tracheobionta

Superdivision : Spermatophyta 


$\begin{array}{lll}\text { Division } & : & \text { Magnoliophyta } \\ \text { Class } & : & \text { Magnoliopsida } \\ \text { Subclass } & : & \text { Asteridae } \\ \text { Order } & : & \text { Gentianales } \\ \text { Family } & : & \text { Apocynaceae } \\ \text { Genus } & : & \text { Thevetia } \\ \text { Species } & : & \text { peruviana }\end{array}$

Synonyms: Cascabela thevetia, Cerbera thevetia, Thevetia neriifolia Common name: Be-still Tree, Suicide Tree, Lucky nut

\author{
Vernacular names:- \\ Hindi: Peeli Kaner, Kulkephul \\ Tamil: Thiruvachipoo, Ponnarali \\ Bengali: Kolkaphul \\ Marathi: Bitti \\ Manipuri: Utonglei \\ Others: Manjaaralie, Shatakunda, Pachaganeru, Ponnarali, Ashvaghna, Ashvamaraka
}

Habitat: Tropical, lowland areas

Morphological Description: Thevetia peruviana is an evergreen shrub or small tree usually about 3-8m tall. The leaves are spirally arranged, linear and about $13-15 \mathrm{~cm}$ in length. Flowers are bright yellow and funnel shaped with spirally twisted. The fruits are somewhat globular, slightly fleshy and have a diameter of $4-5 \mathrm{~cm}$. The fruits, which are green in colour, become black on ripening. Each fruit contains a nut, which is longitudinally and transversely divided. All parts of the plant contain the milky juice.

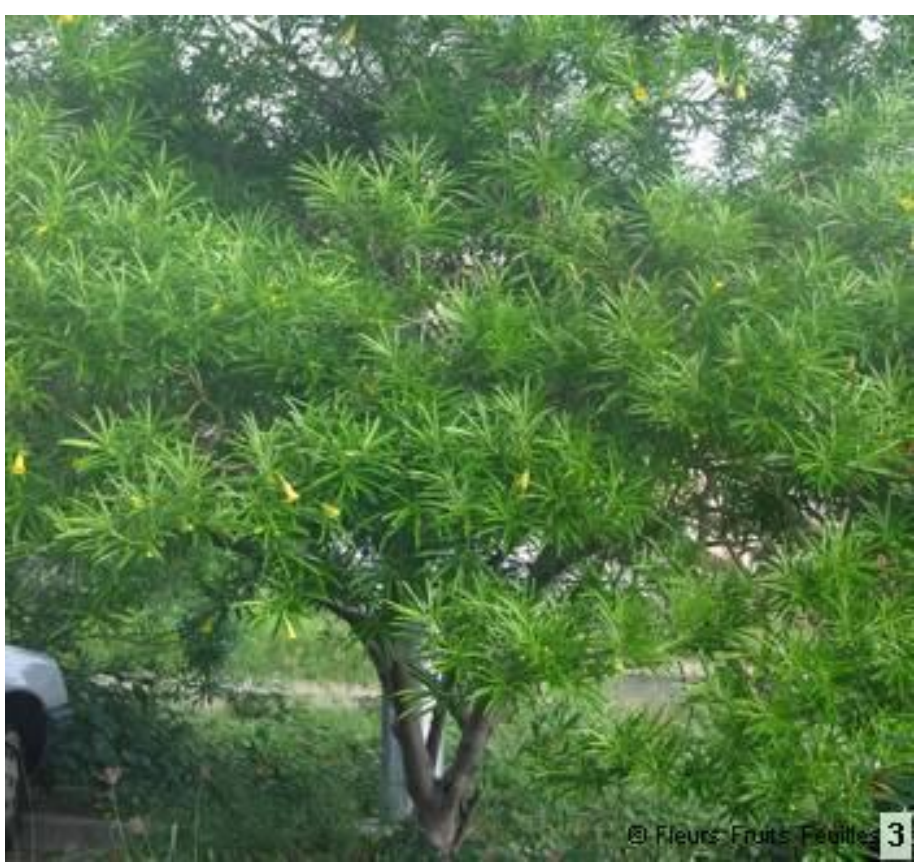

Fig 1:- Thevetia peruviana plant

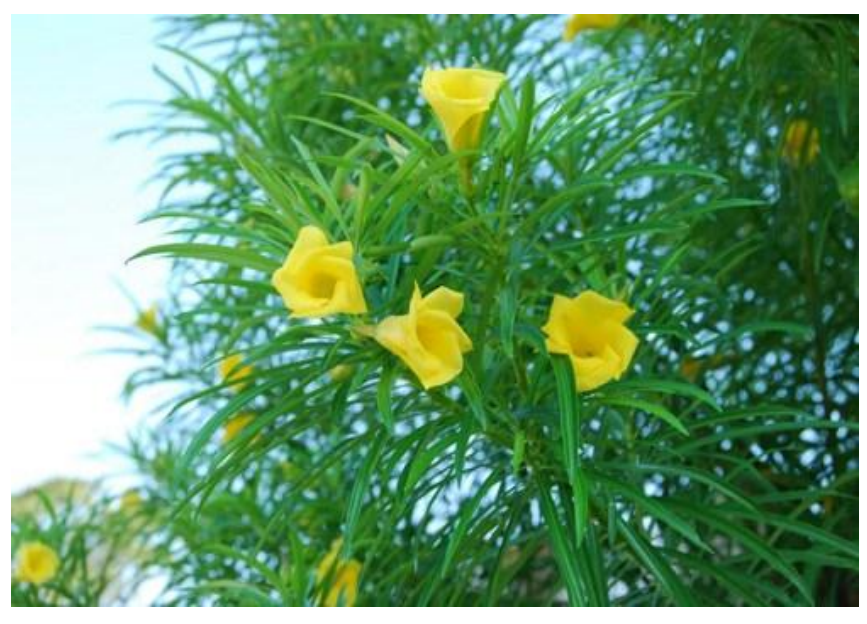

Fig 2:- Thevetia peruviana flowers 


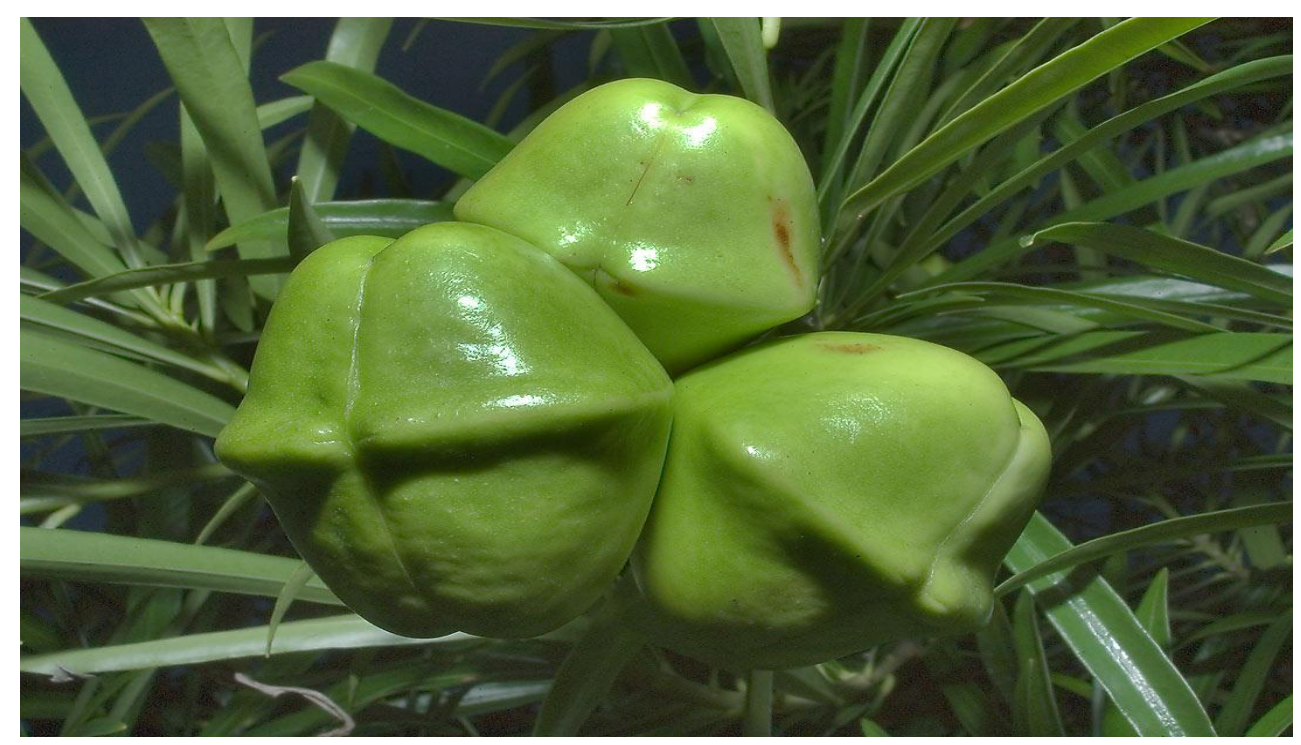

Fig3: Thevetia peruviana fruits

Cultivation and Propagation: Thevetia peruviana cultivation is not much hard. The plant succeeds in full sun or light shade, prefers a fertile, well-drained loam with additional leaf mould, though plants can succeed as well in poor and dry soils. The plant is also tolerant of moderately saline soils. Established plants are drought tolerant. The plants are shallow-rooted and should be sited in positions protected from strong winds. Stem tips of young plants are pinched out to encourage a bushy habit, and established specimens are pruned after flowering or shortly before the growing season to shape and restrict size. The plant can flower and fruit all year round in equatorial climates. The ripe fruits remain on the plant for a long time. The plant responds well to coppicing. Propagated by seed - it has a short viability and is best sown within 3 months of harvesting. Up to $80 \%$ germination rates can be expected.

\section{Phytochemistry:-}

Thevetia peruviana seed kernels are very rich in cardioactive glycosides, triosides i.e. the aglycone of these glycosides consists of three sugar units. The major constitutional glycoside is thevetin. Thevetin is a mixture of two triosides namely Thevetin A and Thevetin B (cereberoside). Seed kernel also contains neriifolin, acetylneriifolin, thevefolin, theveneriin and peruvoside which are monoside in nature. Fatty oils constitute more than $62 \%$ of the seed kernel. Seed also contains small quantity of theveside, viridoside and perusitin. Apigenin-5-methyl ether has been isolated from seed shells.

A number of flavonol glycosides of kaempferol and quercetin have been isolated from the leaves. Leaves also contain polyhydroxy-dinormonoterpenoids and their apiosylglucosides. Epiperuviol acetate, hesperitin-7-glucoside, $\alpha$-and $\beta$-amyrin, kaempferol and quercetin have been isolated from fruit pericarp and flowers. 
Thevetin A-cannogenin (aglycone)

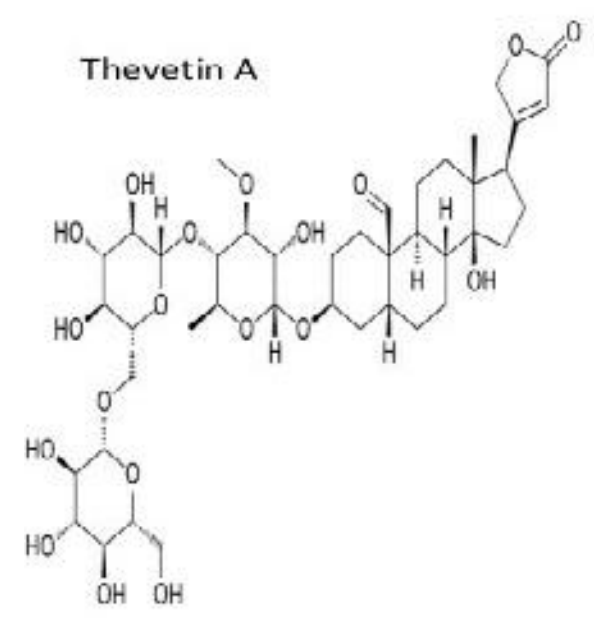

Thevetin B-digitoxigenin(aglycone)

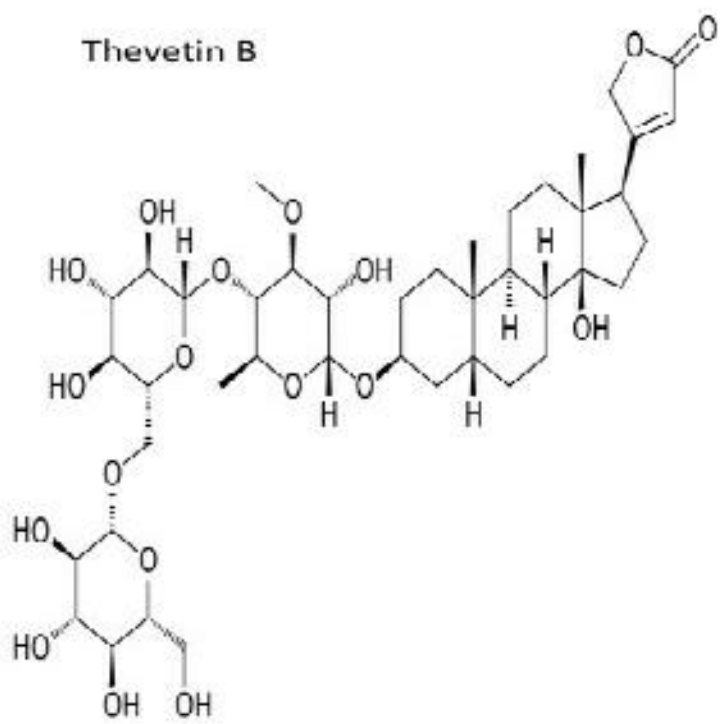

\section{Medicinal Uses:-}

Different parts of Thevetia peruviana are known to possess various medicinal properties (Table1). The plant is commonly used in domestic medicine in tropical America and in tropical Asia. Thevetia peruvina is used traditionally in treatment of amenorrhoea, malarial fever, jaundice, hemorrhoids, constipation, headaches, skin disorders etc.

The main medically active compounds found in the plant are a range of cardiac glycosides. Of these glycosides, peruvoside has been investigated most thoroughly. Large scale clinical trials with 1,600 patients showed that all forms of cardiac insufficiency can be successfully treated with peruvoside. Of the other glycosides thevetin has effectively been used clinically in cases of cardiac decompensation, although its effective dose is rather close to its toxic dose. Thevetin A is far less potent than mixture thevetin. The potency of neriifolin as a cardiac glycoside is only moderate.

The latex is applied to decayed teeth to relieve toothache and is used to treat chronic sores and ulcers. The bark is a powerful antiperiodic and febrifuge. A tincture of the bark is used in the treatment of malarial fever and snakebites. Water in which the leaves and bark have been macerated is taken to cure amenorrhoea.

A decoction of the leaves is taken to treat jaundice, fever and as a purgative for intestinal worms. The leaf sap is used as eye drops and nose drops to cure violent headaches.

The seeds may be used as a purgative when treating rheumatism and dropsy and as an abortifacient. The pulverized seeds are sometimes an ingredient of suppositories to alleviate hemorrhoids. The oil from the kernel is applied topically to treat skin complaints.

Table 1: Traditional uses of different parts of Thevetia peruviana

\begin{tabular}{|c|l|}
\hline Plant Parts & \multicolumn{1}{|c|}{ Traditional Uses } \\
\hline Stem Bark & $\begin{array}{l}\text { Malarial fever, snake bites, febrifuge, purgative, emetic, intermittent fever, sores, } \\
\text { amenorrhoea }\end{array}$ \\
\hline Seeds & $\begin{array}{l}\text { Abortifacient, emetic, hemorrhoids, skin complaints, used as a purgative when treating } \\
\text { rheumatism and dropsy }\end{array}$ \\
\hline Leaves & $\begin{array}{l}\text { Jaundice, fever, as a purgative for intestinal worms, as eye drops and nose drops to cure } \\
\text { violent headaches, colds }\end{array}$ \\
\hline
\end{tabular}




\begin{tabular}{|l|l|}
\hline Roots & Snakebites, made into a plaster and applied to tumors \\
\hline Fruits & Used in ointments and liniments \\
\hline
\end{tabular}

\section{Agroforestry uses:-}

The plant is cultivated as an ornamental plant. Any trimming is best carried out after flowering or shortly before the growing season in order to induce profuse flowering. The plant is grown to provide shade and for soil conservation. It shades out neighboring plants and its litter is allelopathic (releasing substances that discourage the growth of other plants).

Oil obtained from the seeds is used for industry and in soap making. The wood is white and is used to make tool handles and building poles. The wood is also used for fuels.

\section{Biological pest control:-}

The kernels act as a contact poison; mashed with a soap solution they are used as an insecticide. The bark and seeds are used to poison rats.

\section{Pharmacological activities (Table 2):- Antimicrobial activity:-}

The antimicrobial activity of Thevetia peruviana leaves extract with $95 \%$ alcohol as organic solvent was analyzed against ten medically important pathogenic microbes. The extract proved to be effective against Escherichia coli, Klebsiella pneumoniae and Pseudomonas aeruginosa whereas Proteus vulgaris showed susceptibility only at higher doses. The extract also showed moderate anti-microbial activity against Staphylococcus aureus, Candida albicans, Aspergillus niger, Mucor, Rhizopus and Penicillium species (Reddy, 2009).

Thevetia peruviana seed oil was used to make a surface coating. The paint exhibited inhibitory activity against Escherichia coli, Staphylococcus aureus, Bacillus subtilis and Candida albicans in a concentration dependent manner (Kareru et al., 2010). The antimicrobial activity of ethanol leaves extract was tested against Escherichia coli, Salmonella typhi, Vibrio cholera, Shigella and Staphylococcus. The extract showed significant activity against E.coli and Shigella (Mathuravalli and Eswara, 2012).

The antimicrobial potential of the experimental plant leaves extract as compared with callus extract was evaluated. Among the gram-negative bacteria the Pseudomonas aeruginosa seemed to be sensitive against all concentrations of Thevetia peruviana leaf and callus extracts, while Escherichia coli showed resistance with all concentrations of extracts. Callus extract of the plant possess higher activity in comparison with leaf extract against gram-positive (Staphylococcus aureus and Bacillus cereus) and gram-negative (Pseudomonas aeruginosa) strains (Alhashimi et al., 2013).

The antimicrobial activity of seed kernel extracts were analyzed against human skin pathogenic microbes. Antimicrobial efficacy against Pseudomonas aeruginosa, Nocardia asteroids and Candida albicans strains were effective for ethyl acetate than chloroform and methanol fractions, but lower concentrations of chloroform fractions showed higher sensitivity against C. albicans (Nesy and Mathew, 2016).

\section{Antioxidant activity:-}

Antioxidant activities of three morph forms of Thevetia peruviana, Juss fruit wall extracts were evaluated using DPPH free radical scavenging assay. Petroleum ether, chloroform, ethyl acetate and methanol were taken as organic solvents. DPPH free radical scavenging activity exhibited 50\% inhibition for ethyl acetate fraction at a concentration of $1.2 \mathrm{mg} / \mathrm{ml}$ (Nesy and Mathew, 2014).

\section{Antidiabetic activity:-}

The in vivo antidiabetic activity of Thevetia peruviana bark was performed in streptozotocin induced diabetic rats which showed significant activity in a conc. dependent manner (Gogoi and Bhuyan, 2014).

\section{Piscicidal activity:-}

The leaf and bark extracts of Thevetia peruviana was administered for $24 \mathrm{hrs}$. to the freshwater fish Catla catla (Hamilton) to evaluate the piscicidal activity in laboratory and cemented pond condition. The different solvents used were acetone, diethyl ether, ethyl alcohol, chloroform and carbon tetrachloride. The acetone leaf and bark extract of 
this plant was very effective in comparison to other solvent extracts in both the conditions. Exposure of sub-lethal doses $\left(40 \%\right.$ and $80 \%$ of $\mathrm{LC}_{50}$ ) of acetone leaf and bark extract of this plant over $24 \mathrm{~h}$ caused significant ( $\left.\mathrm{p}<0.05\right)$ alterations in total protein, free amino acids, DNA \& RNA, protease and acid and alkaline phosphatase activity, in muscle, liver and gonadal tissues of the experimental fish in laboratory conditions (Singh et al., 2010).

\section{Larvicidal activity:-}

Larvicidal efficacy of methanol leaf extract of Thevetia peruviana was tested against the aquatic stages of Aedes aegypti. The mortality was noticed against I, II, III, IV instar larvae and pupae of A. aegypti after 24 hrs. of treatment with different concentrations $(500-700 \mathrm{ppm})$. In this study IV instar larvae of A.aegypti showed least susceptibility than pupae and larval stages. The mortality rate was increased with concentrations and the larvae also undergo malanization slowly (Sathish et al., 2015).

Leaf extracts of Thevetia peruviana was used to study its larvicidal properties against the larvae of malaria (Anopheles stephensi) and dengue (Aedes aegypti) vectors. Mean $\mathrm{LC}_{50}$ values of the petroleum ether, chloroform, acetone and methanol extracts of leaves of Thevetia peruviana were determined as $0.045,>0.05,0.026,0041$ and $0.038,>0.05,0.021,0.036 \%$, against the larvae of $A$. stephensi and A. aegypti mosquitoes respectively after 24 hours. Delayed impact after 3 days with chloroform extract indicated that the larvicidal action is probably due to the insect growth inhibition (Yadav et al., 2013).

\section{Pesticidal activity:-}

The leaf of Thevetia peruviana were extracted in aqueous and treated against the adults of Holotrichia serrata (Fab.). The tested aqueous leaf extract effectively produced 50\% mortality of Holotrichia serrata (Fab.) and their toxicity was $0.025 \%$ after 48 hours bioassay (Theurkar et al., 2014).

\section{Antifertility activity:-}

The antifertility potential of methanol extract of Thevetia peruviana bark was evaluated. T. peruviana stem bark methanol extract administered orally to male rats at the dose level of $100 \mathrm{mg} / \mathrm{rat} /$ day did not cause any significant reduction in body weight, while the weight of the reproductive organs reduced significantly. A significant fall in the total protein and sialic acid content of the testes, epididymides, seminal vesicles and ventral prostate, as well as in the glycogen content of the testes was also observed; however, cholesterol was increased significantly. The extract also caused a decline in spermatogenic elements, i.e. preleptotene and pachytene spermatocytes, secondary spermatocytes, round spermatids and mature leydig cells. At the mentioned dose level leydig cell nuclear diameter, seminiferous tubular diameter and sertoli cell area were significantly reduced $(\mathrm{p}<0.001)$. The reduction in sperm density and motility resulted in $18 \%$ residual fertility (Gupta et al., 2011)

\section{Antitumor activity:-}

Methanol extracts of Thevetia peruviana fruit showed antitumor activity against Ehrlich's ascites carcinoma (EAC) cell line in Swiss albino mice. The extract treated group's tumor volume, tumor weight and viable cell count were decreased compared to the EAC control group. Tumor volumes were $3.62 \pm 0.12 \mathrm{ml}, 2.88 \pm 0.23 \mathrm{ml}$ and $1.34 \pm 0.17 \mathrm{ml}$ for the EAC control group and the extract treated groups $(50 \mathrm{mg} / \mathrm{kg}$ and $100 \mathrm{mg} / \mathrm{kg}$ body weight), respectively. The extract significantly $(\mathrm{P}<0.001)$ decreased lipid peroxidation and recovered reduced glutathione, superoxide dismutase and catalase toward normal levels compared to the EAC control group (Haldar et al., 2015).

A screening study for TRAIL resistance-overcoming activity was carried out. Cardenolide glycosides from $T$. peruviana were shown to have a significant reversal effect on TRAIL resistance in human gastric adenocarcinoma cells, and real- time PCR showed that thevefolin enhanced mRNA expression of death receptor 4 (DR4) and death receptor 5 (DR5). In addition, 1H and 13C NMR characterizations are shown for thevefolin (Miyagawa et al., 2009).

Table 2:- Some of the most important pharmacological properties of Thevetia peruviana plant parts in different extracts.

\begin{tabular}{|lccc|}
\hline Medicinal Properties & Plant part & Extract & Reference \\
\hline Antidiabetic & Bark & Methanol & Goggoi and Bhuyan, 2014 \\
Antifertility & Bark & Methanol & Gupta et al., 2011 \\
& & & \\
\hline
\end{tabular}




\begin{tabular}{|lccc|}
\hline Antioxidant & Fruit & $\begin{array}{c}\text { Petroleum ether, } \\
\text { chloroform, ethyl acetate } \\
\text { and methanol }\end{array}$ & $\begin{array}{c}\text { Nesy and Mathew, } \\
2014\end{array}$ \\
Anticancer & Fruit & Methanol & Haldar et al., \\
Larvicidal & Leaves & $\begin{array}{c}\text { Petroleum ether, } \\
\text { chloroform, } \\
\text { acetone and methanol } \\
\text { Antimicrobial }\end{array}$ & $\begin{array}{c}\text { Sathish et al., } \\
2015\end{array}$ \\
& Seed & $\begin{array}{c}\text { Ethyl acetate } \\
\text { chloroform } \\
\text { and } \\
\text { methanol }\end{array}$ & $\begin{array}{c}\text { Nesy and Mathew, } \\
2016\end{array}$ \\
& & & \\
\hline
\end{tabular}

\section{Toxicity:-}

All parts of the plant produce latex that is highly poisonous; the kernels are the most toxic. The active principles are cardiac glycosides of the cardenolide type; symptoms of poisoning mainly involve the cardiovascular system (including various types of arrhythmia, e.g. sinus bradycardia) and the gastro-intestinal tract. Vomiting is the common symptom in poisoning in about $30 \%$ of all cases. Ischemic changes occur in about $40 \%$ of the cases, as well as palpitations in about $10 \%$. The most serious and immediate cause leading to death is peripheral vascular failure. The seeds have been used for committing suicide, homicide, as an ordeal poison. The absorption of the equivalent of two Thevetia peruviana leaves may be sufficient to kill a $12.5 \mathrm{~kg}$ child (Ellenhorn and Barceloux, 1988).

A comparative study of the toxic effects of extracts from stem bark, leaf and seed kernel of yellow oleander (Thevetia peruviana) in albino rats was carried out. Extracts from all the plant parts were toxic, and produced marked poisoning symptoms that culminated in death. Poisoning symptoms manifested earlier (10 min after treatment) in rats administered aqueous kernel extracts intraperitoneal as against 45 min to several hours in rats poisoned by ingestion of toxicant. Poisoning symptoms indicated serious cardiac, neuromotor and mental malfunctioning, and manifested as tachycardia, arrhythmia, paralysis, ataxia and disorientation. Rats treated by injection with aqueous kernel extract died faster within $10 \mathrm{~h}$, than those with the aqueous leaf or stem bark extracts, that died after $260 \mathrm{~h}$ (Oji and Okafor, 2000).

\section{Conclusion:-}

In the present study, Thevetia peruviana belonging to the family of Apocynaceae, having several bioactive constituents is reviewed with special emphasis on the biological activities. In the traditional medicine, various plant parts such as leaves, bark, seeds, fruit are used for different types of disorders. The plant possess many secondary metabolites especially glycosides and have various pharmacological activities as discussed in the present paper. In contrast to the traditional claims, very few scientific works of medicinal interest have so far been carried out in this plant. However, it is imperative that more clinical and more pharmacological studies should be conducted to explore the potential of this plant.

\section{Conflict of Interest:-}

No conflict of interest 


\section{References:-}

1. Alhashimi, S.K.M., Rashid, K.I., Saleh, G.S., Abdulhadi, A.M. and Taher, T.A. (2013): The anti-microbial activity of leaves and callus extracts of Thevetia peruviana in vitro. J Biotech Res Cen, 7: 10-15.

2. Ellenhorn, M.J. and Barceloux (1988): Medical toxicology: diagnosis and treatment of human poisoning. Elsevier, San Diego.

3. Gogoi, N. and Bhuyan, B. (2017): In vivo antidiabetic activity evaluation of the bark of Cascabela thevetia L. in streptozotocin induced diabetic rats. Int J Pharm Pharm Sci, 9: 48-53.

4. Gupta, R., Kachhawa J.B.S., Gupta, R.S., Sharma, A.K., Sharma, M.C. and Dobhal, M.P. (2011): Phytochemical evaluation and antispermatogenic activity of Thevetia peruviana methanol extract in male albino rats. Hum Fertil, 14: 53-59.

5. Haldar, S., Karmakar, I., Chakraborty, M., Ahmad, D. and Haldar, P.K. (2015): Antitumor potential of Thevetia peruviana on Ehrlich's Ascites Carcinoma - Bearing Mice. J Environ Pathol Toxicol Oncol, DOI: 10.1615/J Environ Pathol Toxicol Oncol.2015012017.

6. Mathuravalli, K. and Eswara, R.L. (2012): Analysis of phytochemical components and anti-microbial activity of the toxic plant Thevetia peruviana. Ind J Inn Dev, 1: 97-101.

7. Miyagawa, T., Ohtsuki, T., Koyano, T., Kowithayakorn, T. and Ishibashi, M. (2009): Cardenolide glycosides of Thevetia peruviana and triterpenoid saponins of Sapindus emarginatus as TRAIL resistance overcoming compounds. J Nat Prod, 72: 1507-11.

8. Nesy, E.A. and Mathew, L. (2016): In vitro cytotoxicity and anti-microbial efficacy of Thevetia peruviana seed kernel extracts. Int J Pharm Pharm Sci, 8: 47-50.

9. Nesy, E.A., and Mathew, L.A. (2014): Comparative evaluation of anti-microbial and anti-oxidant properties of Thevetia neriifolia juss fruit rind extracts. Int J Curr Pharm Res, 6: 47-50.

10. Oji, O. and Okafor, Q.E. (2000): Toxicological studies on stem bark, leaf and seed kernel of yellow oleander (Thevetia peruviana). Phytother Res, 14: 133-135.

11. Reddy, B.U. (2010): Anti-microbial activity of Thevetia peruviana (Pers.) K. Schum. and Nerium Indicum Linn. Internet J Pharmacol, 8: 2.

12. Sathish, V., Umavathi, S., Thangam, Y. and Mathivanan, R. (2015): Analysis of phytochemical components and larvicidal activity of Thevetia peruviana against the chickungunya vector Aedes aegypti (L). Int J Curr Microbiol Appl Sci, 4: 33-39.

13. Singh, S.K., Yadav, R.P. and Singh, A. (2010): Piscicidal activity of leaf and bark extract of Thevetia peruviana plant and their biochemical stress response on fish metabolism. Eur Rev Med Pharmacol Sci, 14: 915-923.

14. Theurkar, S.V., Patil, S.B., Ghadage, M.K., Birhade, D.N. and Gaikwad, A.N. (2014): Investigation on effect of Thevetia peruviana (Pers.) on the mortality of Holotrichia serrata (Fab.) adults (Coleoptera: Scarabaiedae). Int Res J Pharm, 5: 212-214.

15. Yadav, S., Singh, S.P. and Mittal P.K. (2013): Toxicity of Thevetia peruviana (yellow oleander) against larvae of Anopheles stephensi and Aedes aegypti vectors of malaria and dengue. J Entomol Zool Stud, 1: 85-87. 